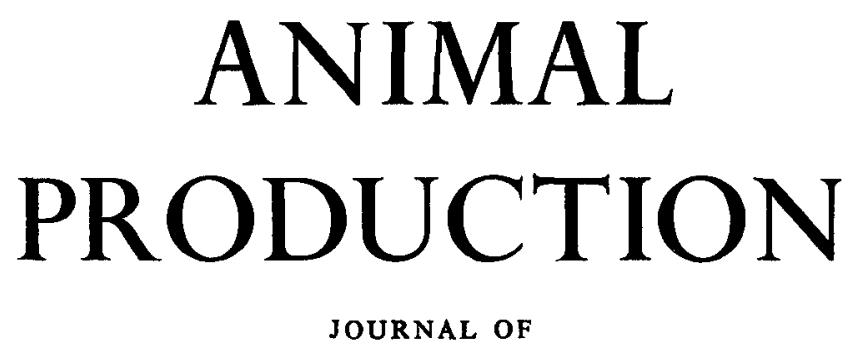

THE BRITISH SOCIETY OF ANIMAL PRODUCTION

\author{
Edited by \\ J. A. F. ROOK \\ M. BICHARD (Proceedings) \\ W. G. HILL \\ J. HODGSON \\ A. M. RAVEN \\ J. C. TAYLER \\ A. J. F. WEBSTER \\ M. B. WILLIS
}

VOLUME 22

1976

LONGMAN 
PRINTED IN GREAT BRITAIN BY

T. \& A. Constable Limited, Eoingurgh 


\section{CONTENTS OF VOLUME 22}

(LISTED ALPHABETICALLY BY AUTHOR)

PAGE

Allen, W. M., see Litrie, W.

Ball, C., see Broadbent, P. J.

Bar-ANan, R., Soller, M. and Bowman, J. C. Genetic and environmental factors affecting the incidence of difficult calving and perinatal calf mortality in Israeli-Friesian dairy herds

Bowman, J. C., see Bar-ANan, R.

Bradford, G. E., see KoONG, LING-Jung, see also EkLund, J.

BroadBent, P. J., Ball, C. and Dodsworth, T. L. Effects of using rations of reduced energy concentration for intensively reared beef cattle from $250 \mathrm{~kg}$ live weight to slaughter.

BRYANT, M. J. and TOMKINs, T. The flock-mating of progestagen-synchronized ewes. 2. The influence of time of ram introduction upon mating behaviour and lambing performance

BRYANT, M. J., see also Tomkins, T.

Burr, A. C., see Smith, W. C.

CARR, J. R., see COLE, D. J. A.

Church, D. C., see Mehren, M. J.

Clark, J. B. K., see SMTh, W. C.

Cole, D. J. A., White, M. R., HARdy, B. and CARR, J. R. Tissue growth in the pig.

Cole, D. J. A., see also VARLey, M. A.

Davison, C., see Wilson, A.

Dickson, I. A. and LAIRD, R. Dried sugar-beet pulp as a roughage substitute for pregnant ewes.

Dodsworth, T. L., see Broadbent, P. J.

DrennaN, M. J. and LAWLOR, M. J. Evaluation of pelleted dried grass as a supplement to grass silage for fattening steers

DUCKER, M. J. and Fraser, J. A note on the effect of time of uptake of colostrum on blood gamma-globulin levels, mortality and subsequent performance of housed lambs . $\quad . \quad$. $\quad . \quad$. $\quad . \quad$.

Ducker, M. J., Fraser, J. and Hemingway, R. G. Evaluation of molassed sugar-beet pulp nuts supplemented with urea as an energy and protein source for lactating ewes .

Edwards, I. E., see Hinks, C. E.

EkLund, J. and BradFord, G. E. A note on short term selection for birth weight in mice

FARID, A., see PASDAR, M.

FAwCETt, R. H., see WhITtEMore, C. T.

Field, A. C., see WiEnER, G. 
FolmaN, Y., see LeVY, D.

Fraser, J., see Ducker, M. J.

GORDON, F. J. Effect of concentrate level and stocking rate on performance of dairy cows calving in late winter .

GRIFFITHS, R. G., see SYKES, A. R.

HANRAHAN, J. P. Maternal effects and selection response with an application to sheep data .

Hardy, B., see Cole, D. J. A.

Hayter, Susan, see Wiener, G.

HELle, T., see HyvärINEN, $H$.

Hemingway, R. G., see Ducker, M. J.

Hemsworth, P. H., Winfield, C. G. and Mullaney, P. D. Within-litter variation in the performance of piglets to three weeks of age

Henderson, A. R., see Hinks, C. E.

Hill, W. G., see Sales, Jill

Hinks, C. E., Edwards, I. E. and Henderson, A. R. Beef production from formic-acid-treated and wilted silages

Hinks, C. E. and WhitTemore, C. T. A note on the utilization by calves of maize and potato diets in liquid suspension or in dry form

Hodges, J., see Wood, P. D. P.

Holmes, W., see Uмон, J. E., see also Horton, G. M. J.

Holzer, Z., LeVy, D., Tagari, H. and Volcani, R. Soaking of complete fattening rations high in poor roughage. 3. The effect of moisture content and spontaneous fermentation on the performance of male cattle

Holzer, Z., Tagari, H., Levy, D. and Volcani, R. Soaking of complete fattening rations high in poor roughage. 2. The effect of moisture content and of particle size of the roughage component on the performance of male cattle .

Holzer, Z., see also LeVY, D.

Hooper, A. C. B. and MCCarthy, J. C. A note on fibre number and diameter in muscles of large and small lines of mice compared at a fixed body weight .

Horton, G. M. J. and Holmes, W. A note on the influence of a supplement of barley and dried lucerne on the intake of barley straw by cattle .

Hyvärinen, H., Helle, T., Nieminen, M., Väyrynen, P. and Väyrynen, RaIJA. Some effects of handling reindeer during gatherings on the composition of their blood

ILAN, D., see LEVY, D.

KAY, R. M., LitTLe, W. and Kitchenham, B. A. A comparison of the growth performance and blood composition of twin and singleton calves

KING, J. W. B., see WEBB, A. J.

KItchenhaM, B. A., see Kay, R. M.

KOONG, LING-JUNG, and BraDFord, G. E. Effects of stage of gestation and litter size on prenatal growth in the mouse 
LAIRD, R., see DICKșon, I. A.

LAWLOR, M. J., see DRENNAN, M. J.

LeVY, D., Holzer, Z. and Folman, Y. Effects of plane of nutrition, diethylstilboestrol implantation and slaughter weight on the performance of Israeli-Friesian intact male cattle

LeVY, D., Holzer, Z. and IlaN, D. Effect of dietary energy content at different stages of growth on performance of intact male cattle

Levy, D., see also Holzer, Z.

Little, W., Sansom, B. F., Manston, R. and Allen, W. M. Effects of restricting the water intake of dairy cows upon their milk yield, body weight and blood composition

LiTtLE, W., see also KAY, R. M.

LUDWICK, T. M., see SHARMA, D. P.

McCarthy, J. C., see Hooper, A. C. B.

MCILMOYLE, W. A. Effect of silage additives on the intake and performance of male calves and steers

Makarechian, M., see Pasdar, M.

MANSTON, R., see LitrLe, W.

MARSH, R. Intake by and performance of early-weaned calves offered unwilted or wilted silage supplemented with a cereal and protein concentrate or dried grass

Mehren, M. J. and Church, D. C. Influence of taste-modifiers on taste responses of pygmy goats

Mullaney, P. D., see Hemsworth, P. H.

NAPIER, K. M., see Thatcher, L. P.

Nieminen, M., see HYVÄrinen, $H$.

Pasdar, M., Makarechian, M. and Farid, A. A note on the association between transferrin types and some productive traits in Iranian sheep .

Russell, W. S. Effect of twin birth on growth of cattle . . . . .

SALES, Jill and HiLl, W. G. Effect of sampling errors on efficiency of selection indices. 1. Use of information from relatives for single trait improvement .

Sansom, B. F., see Little, W.

Saubidet, C. L. and Verde, L. S. Relationship between live weight, age and dry-matter intake for beef cattle after different levels of food restriction

Sharma, D. P. and Ludwick, T. M. A note on sperm survival in relation to chloride content in bull semen .

SleE, J., see Sykes, A. R.

Smith, W. C., Wilson, A., Burr, A. C. and Clark, J. B. K. A note on muscle $\mathrm{pH}_{1}$ values in commercial pig carcasses .

SOller, M., see BAR-ANAN, R.

Sykes, A. R., Griffiths, R. G. and SleE, J. Influence of breed, birth weight and weather on the body temperature of newborn lambs

TAGARI, H., see HolzER, Z. 
Thatcher, L. P. and NAPIER, K. M. Economic evaluation of selecting sheep for wool production

TOMKINS, T. and BRYANT, M. J. Influence of mating pressure and season on the semen characteristics of rams

Tomkins, T., see also BRyANT, M. J.

UMOH, J. E. and Holmes, W. A note on ensiled ear maize and barley in finishing rations for beef cattle

VARLEY, M. A. and Cole, D. J. A. Studies in sow reproduction. 4. The effect of level of feeding in lactation and during the interval from weaning to remating on the subsequent reproductive performance of the earlyweaned sow

VARLeY, M. A. and Cole, D. J. A. Studies in sow reproduction. 5. The effect of lactation length of the sow on the subsequent embryonic development .

VÄYRYNEN, P., see HyVÄrinEN, H.

VÄYRYNEN, RAIJA, see HYVÄRINEN, H.

Verde, L. S., see Saubidet, C. L.

VOLCANI, R., see Holzer, Z.

WEBB, A. J. Development of a synthetic pig sire line by selection with immigration. 2. Immigration .

WEBB, A. J. and KING, J. W. B. Development of a synthetic pig sire line by selection with immigration. 1. Results of selection and heritability estimates

White, M. R., see Cole, D. J. A.

Whittemore, C. T., and FAwCett, R. H. Theoretical aspects of a flexible model to simulate protein and lipid growth in pigs

WhitTemore, C. T., see also Hinks, C. E.

Wiener, G., Hayter, Susan and Field, A. C. Selection for plasma copper concentrations within haemoglobin type in sheep

Willis, M. B., see WiLson, A.

Wilson, A., Willis, M. B. and Davison, C. Factors affecting calving difficulty and gestation length in cows mated to Chianina bulls and factors affecting the birth weight of their calves

Wilson, A., see also Smith, W. C.

Winfield, C. G., see Hemsworth, P. H.

Wood, P. D. P. Algebraic models of the lactation curves for milk, fat and protein production, with estimates of seasonal variation

WooD, P. D. P. A note on detection of oestrus in cattle bred by artificial insemination, and the measurement of embryonic mortality

WooD, P. D. P. and Hodges, J. Comparative methods of testing Hereford $\times$ Friesian progeny groups for growth and carcass characters .

Proceedings of the 62ND Meeting of the British Society of Animal Production, Harrogate, 15-17 March 1976. 
Tables should be as simple and as few as possible. When constructing tables, it would be helpful if authors would take into account the size and shape of the pages of Animal Production.

Summary: Every article should have a short summary (not more than 250 words) complete in itself and understandable without reference to the paper. The summary will be printed at the beginning of the paper.

References: Only papers closely related to the author's work should be referred to; exhaustive lists should be avoided. Bibliographical details should be in the following order: author's name, initials, year, title of paper, title of journal (abbreviated according to the World List of Scientific Periodicals), volume of journal, first and last page of paper. References should be listed in alphabetical order. When abstracts are referred to, the page reference should be followed by (Abstr.).

\section{Examples:}

BLAXTER, K. L. and WiLSON, R. S. 1962. The voluntary intake of roughages by steers. Anim. Prod. 4: 351-358.

Hammond, J. 1932. Growth and the Development of Mutton Qualities in the Sheep. Oliver and Boyd, Edinburgh.

In the text, references should be made by giving author and year; at the first mention all authors should be named, thereafter the first author followed by $e t$ al. should be used for papers with more than two authors.

Proofs are supplied once and must be returned corrected to the Editors within seven days. Only essential corrections should be made.

Reprints: Twenty-five reprints of each paper will be supplied free to authors on request. Further copies may be purchased if the order is sent at the proof stage.

Animal Production is published six times a year in two volumes. Annual subscription is $£ 20.00$ (or $\$ 56.00$ in the U.S.A. and Canada) and the price for a single part is $£ 4.00$ (or $\$ 12.00$ ) net.

Proceedings of the British Society of Animal Production (New Series) ceased publication in 1975 and the material is now published as a separate section of the February issue of Animal Production.

Business matters, including regular subscriptions and sales (current and back numbers of the Journal and the Proceedings) should be addressed to Longman Group, Journals Division, 43/45 Annandale Street, Edinburgh EH7 4AT.

\section{Senior Editor}

J. A. F. Rook, Hannah Research Institute.

\section{Editors}

M. BiCHARD, Pig Improvement Company (Proceedings).

W. G. HiLL, Institute of Animal Genetics.

J. Hodgson, Hill Farming Research Organisation.

A. M. Raven, West of Scotland Agricultural College.

J. C. TAYLER, Grassland Research Institute.

A. J. F. WEBSTER, Rowett Research Institute.

M. B. WiLLIs, University of Newcastle-upon-Tyne. 


\section{CONTENTS}

Wood, P. D. P. and Hodges, J. Comparative methods of testing Hereford $x$ Friesian progeny groups for growth and carcass characters .

Bar-Anan, R., Soller, M. and Bowman, J. C. Genetic and environmental factors affecting the incidence of difficult calving and perinatal calf mortality in Israeli-Friesian dairy herds

MARSH, R. Intake by and performance of early-weaned calves offered unwilted or wilted silage supplemented with a cereal and protein concentrate or dried grass

McIlmoyle, W. A. Effect of silage additives on the intake and performance of male calves and steers .

Little, W., Sansom, B. F., Manston, R. and Allen, W. M. Effects of restricting the water intake of dairy cows upon their milk yield, body weight and blood composition .

Cole, D. J. A., White, M. R., Hardy, B. and CarR, J. R. Tissue growth in the pig

Hemsworth, P. H., Winfleld, C. G. and Mullaney, P. D. Within-litter variation in the performance of piglets to three weeks of age . .

HANRAHAN, J. P. Maternal effects and selection response with an application to sheep data .

TOMkINS, T. and BRYANT, M. J. Influence of mating pressure and season on the semen characteristics of rams

Bryant, M. J. and Tomkins, T. The flock-mating of progestagen-synchronized ewes. 2. The influence of time of ram introduction upon mating behaviour and lambing performance

Wiener, G., Hayter, Susan and Field, A. C. Selection for plasma copper concentrations within haemoglobin type in sheep

Sykes, A. R., Griffiths, R. G. and Slee, J. Inffuence of breed, birth weight and weather on the body temperature of newborn lambs

Ducker, M. J., Fraser, J. and Hemingway, R. G. Evaluation of molassed sugar-beet pulp nuts supplemented with urea as an energy and protein source for lactating ewes.

Ducker, M. J. and Fraser, J. A note on the effect of time of uptake of colostrum on blood gamma-globulin levels, mortality and subsequent performance of housed lambs.

Hinks, C. E. and Whirtemore, C. T. A note on the utilization by calves of maize and potato diets in liquid suspension or in dry form .

Horton, G. M. J. and Holmes, W. A note on the influence of a supplement of barley and dried lucerne on the intake of barley straw by cattle

Sharma, D. P. and Ludwick, T. M. A note on sperm survival in relation to chloride content in bull semen . 